الإحتياجات التدريبة للمرشدات الزراعيات فى مجال تخطيط البرامج الإرشادية للحفاظ على البيئة الريفية بمحافظة الغربية

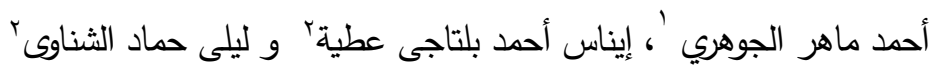

1- وجود علاقة إرتباطية معنويـة عند مستوى إحتمـالي ا ...

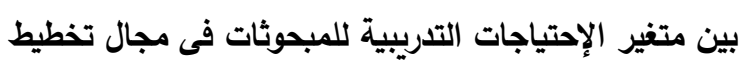
البرامج الإششادية للحفاظ على البيئة الريفية وكل من الخبرة

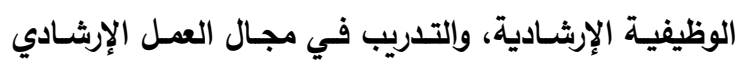

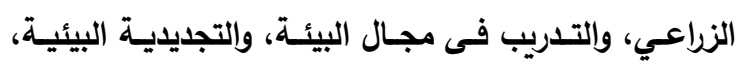

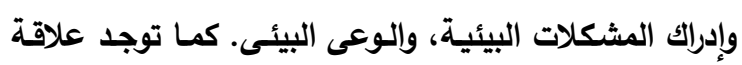

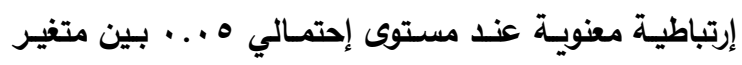

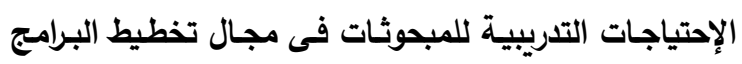

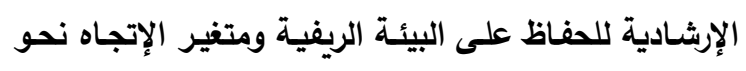

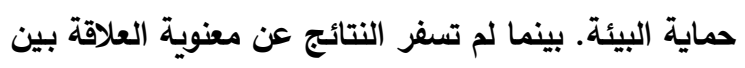

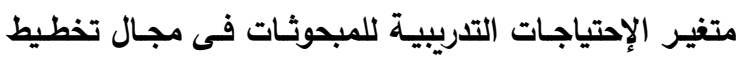
البـرامج الإرشـادية للحفـاظ على البيئسة الريفيـة ومتفيـري

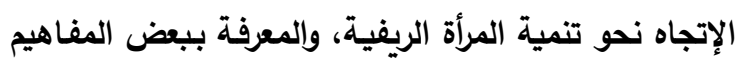
البيئية.

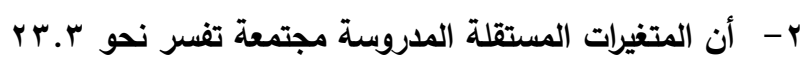
\% من التباين في متغير الإحتياجات التدريبية للمبحوثات

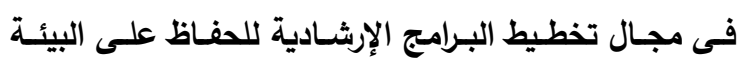
الريفية.

الكلمات المفتاحية: الإحتياجات التدربيية ـ البرامج الإرشادية

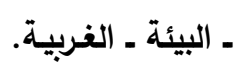

\section{المقدمة والمثكلة البحثية}

يمكن القول بأن قضية البيئة هي قضية العصر، فإذا كان لكل عصر قضية تفرض نفسها وتثغل عقول المفكرين فإن قضية هذا العصر هي البيئة، وربما يرجع ذلك إلى نضوب وإستتزاف الموارد البيئية وتردي أحوال البيئة في أجزاء

$$
\text { الملخص العربى }
$$

إسـتهدف هـا البحث بصـفة أساسية قيـاس الإحتياجـات التدريبية للمرشدات الزراعيات فى مجال تخطيط البرامج الإرشادية

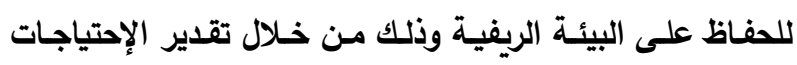

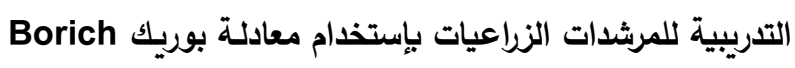

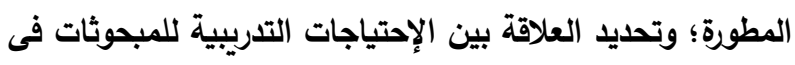

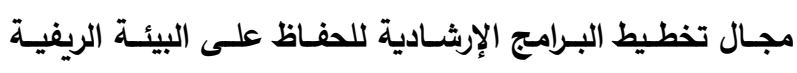

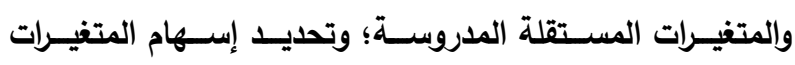
المستقلة المدروسـة فـى تفسير التباين فـى متغير الإحتياجـات

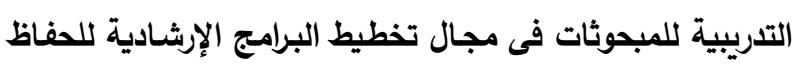

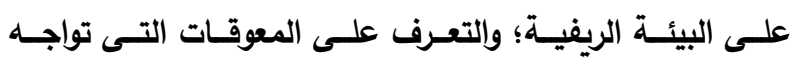

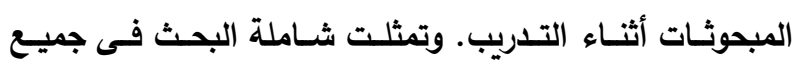
المرثدات الزراعيات على مستوى القرية بمحافظة الغربية والبالغ عددهن ^r r مرشدة زراعية، وتقرر إختيار عينة عثوائية منهن

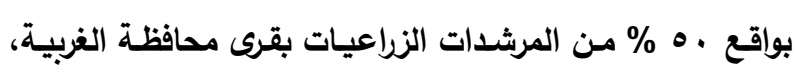

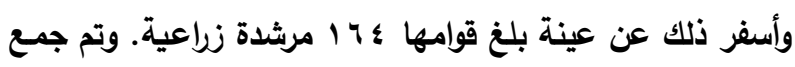

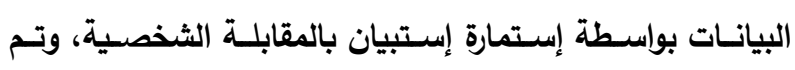

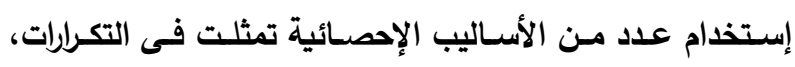
والنسب المئوية، والمتوسط الحسابي، ومعامل ثبات ألفا كرونباخ، ومعامـل الإرتباط البسيط لبيرسيون، وأسـلوب التحليل الإرتباطي والميطي

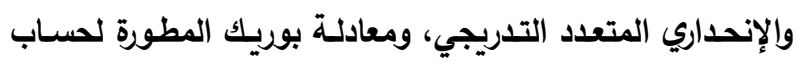
الإحتياجات التدربيية للمبحوثات.

وتمثلت أهم النتائج التي أسفرت عنها هذه الاراسة فيما القسم الاقتصاد الزراعى - كلية الزراعة - جامعة طنطا الإيميل: ahmed.elgouhari@agr.tanta.edu.eg بمعهد بحوث الارشاد الزراعى والتمية الريفية - مركز البحوث الزراعية - الجيزة

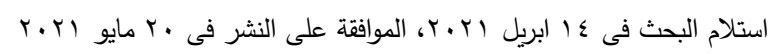




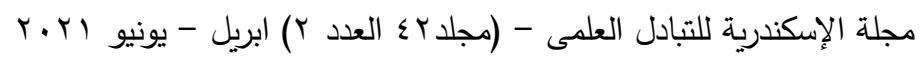

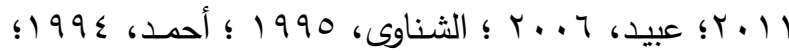

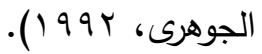
فمشكلات البئُة الريفيـة ترجـع للسـلوكيات الإنسـانية اللاواعيـة، فهـي مشككلات إنسـانية تتعلـق في المقـام الأول بسلوك الإنسان وموقفة من الطبيعة، وحتى تعود البيئة الريفية إلى هيئتها وإتزانها ينبخي أن يعدل الأفراد من سلوكهم الحالي الضـار بالبيئة، وأن يتخلى الأفراد عن إسـرافهم في إستخدام موارد البيئة وتلويثها والعبث بقوانينها الأزلية مهما كانت الغاية من ذلك إستثماراً أو إستغلالاً أو رفاهية. الأمر الذي يستوجب إعادة النظر في أسلوب التعامل البشري مع البيئة، والتعامل الرشـيد مـع المـوارد البيئيـة، حتى يمكن إعـادة التوازن بـين مكوناتها والتغلب على العديد من المشكلات التي تهدد حياة

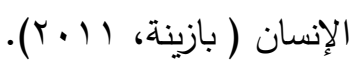

ولا يخفى عن أحد من المرتمين بقضـايا البيئة وخاصـة

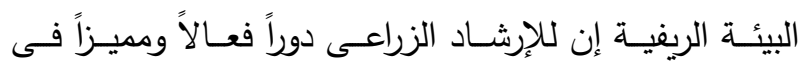
التصدى لمشكلات البيئة، بإعتباره أحد النظم التعليمية المنوط بها تميـة الـوعى البيئى للـريفين، وذلك عـن طريـق إعـداد وتخطيط وتتفيذ برامج إرشادية فعالة تتمشى مع الواقع البيئى للمجتمعـات الريفيـة، وفى إطـار إسـتراتيجية الدولــة للتتميـة الريفية يمكن من خلالها إحداث التغيرات السلوكية المرغوبـة إلهات فى المسترشدين بصفة عامـة والريغيات بصفة خاصـة، وذلك من منطلق كونهن يمثلن القاعدة العريضــة اللازمـة لحمايـة البيئة والعمـل على تتميتهـا مـن خـلال ممارسـاتهن البيئيـة

$$
\text { اليومية (عطية، } 99 \text { (ب). }
$$

ويعتبر التخطيط للعمـل الإرشـادى الزراعي هو دراسـة

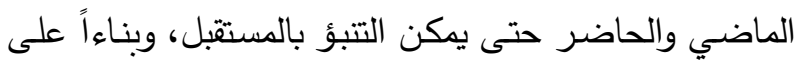

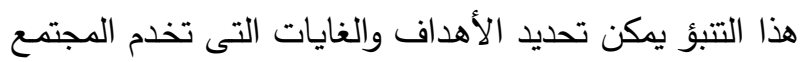

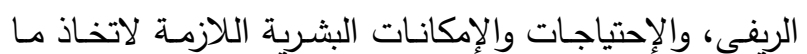
يلـزم مـن إجـراءات مـع تحديـد الطريقــة والمكــان المناسـبين

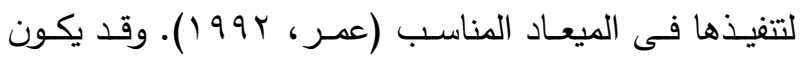
التخطيط مهمـة صـعبة في المجتمعـات بصـفة عامـة وفى
كثيرة من الكرة الأرضية إلى درجة أنها أصبحت لا تصلح

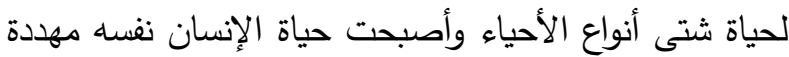

$$
\text { بالخطر ( النكلاوي، } 999 \text { (؛ شربي، . . . ؟). }
$$

وإزداد فى الآونـة الأخيرة الحديث عن مشكلات البيئة حتى أصبحت مشكلات البيئة وقضاياها هى الشغل الثـاغل لكل دول العالم، لا فرق في ذلك بين الدول المتقدمة والدول الناميـة، ليس هذا فحسب فقد أصسبح الإهتمـام بالبيئة غير مقصور على الإهتمام الرسمى فقط، بل أصبح إهتماما يشغل

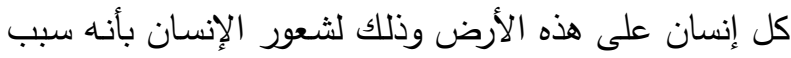
بل أهم أسباب هذه المشكلات البيئية. وبالرغم من أن الوعي

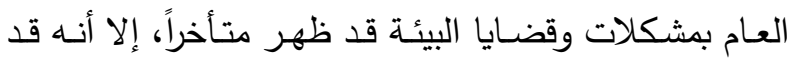

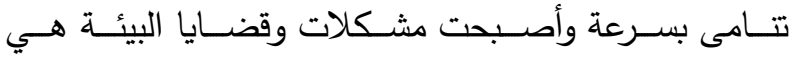
الموضسوع الرئيسي لكثير من المؤتمرات والندوات التي تعقد عبر المنظمـات والهيئـات الدوليـة والإقليميـة والمحليـة، وكذا

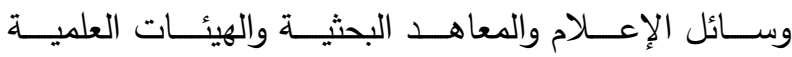
المتخصصة، كما أنشئت هيئة متخصصة بشئون البيئة تابعة للأمم المتحدة تحت مسمى برنامج الأمم المتحدة لشئون البيئة UNEP

$$
\text { (Y... T) }
$$

وتعانى مصر - مثل بقية الدول على كوكب الأرض - من مشكلات بيئية عديدة في الريف والحضر على السواء. فـالريف المصـري يواجـه أخطـار بيئيـة ناتجـة عن سـلوكيات غير واعية بيئياً تتمثل في تجريف وتبوير الأرض الزراعية،

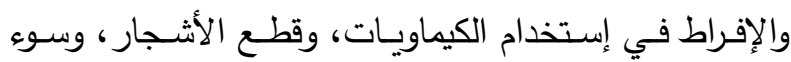
إستخدام مياه الري وتلويثها، وسوء التخلص مـن المخلفات المزرعية. إلى جانب ذلك فإن للمرأة الريفيـة سلوكيات غير

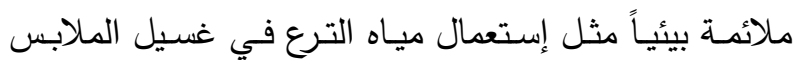
والأدوات المنزلية، وإستحمام الأطفال في مياه الترع، وعدم الإهتمام بصحة بيئة المسكن، ومشاركة الحيوان الزراعي في

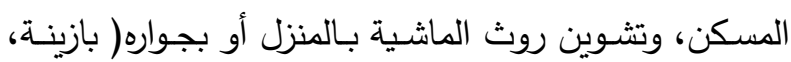


كما أوضحت الدراسة وجود علاقة إرتباطية معنوية بين كل من السن، وعدد سنوات الخبرة بالزراعة، وعدد سنوات الخبرة بالعهل الإرشـادي، ومدة التدريب السابق وبين الإحتياجـات

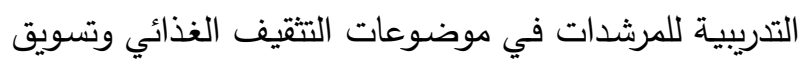
المحاصيل، والتفصيل والخياطة، وبعض المهارات مثل مهارة

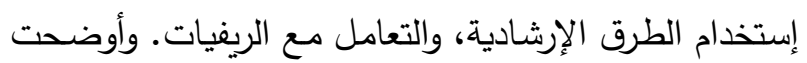

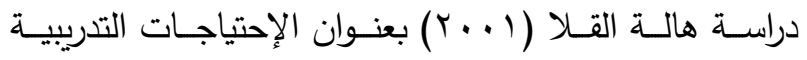

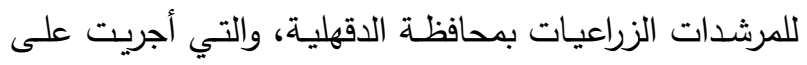

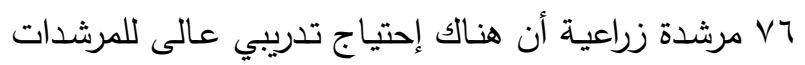
الزراعيات في مجالات مثل الأنشطة والمهام التي تقوم بها

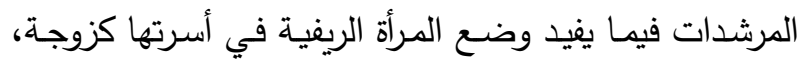

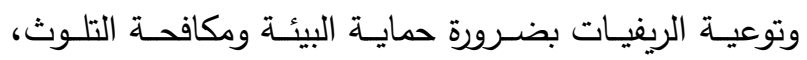
وتوعية الريفيات في مجال الصحة العامة؛ كما يوجد إحتياج

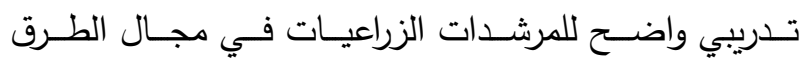

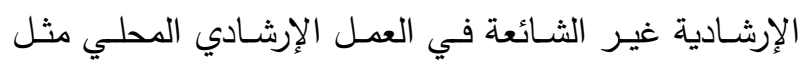

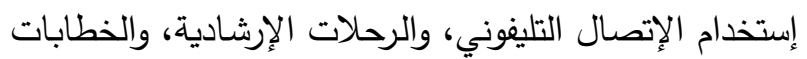

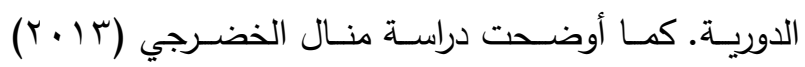
بعنـوان الإحتياجـات التدريبيـة لتتميـة مهـارات الإتصـال للمهندات الزراعيات العاملات بالإرشاد الزراعي في محافظة

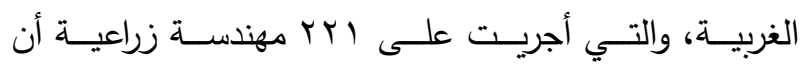
المبحوثات في حاجة إلى التدريب على المجالات الفنية التي

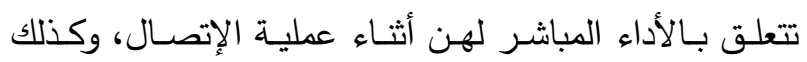

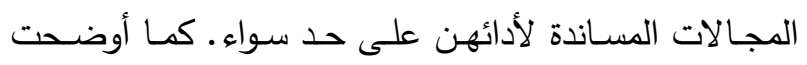

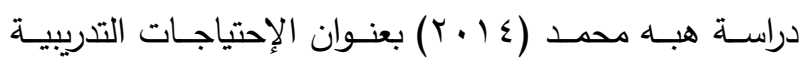

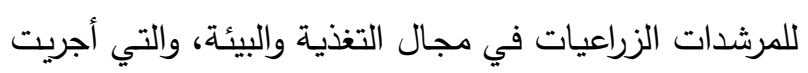
على §؟ ا مرشدة زراعية أن ما يقرب من نصف المبحوثات

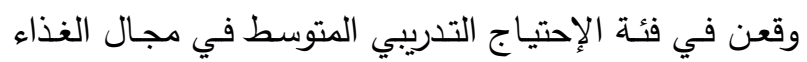

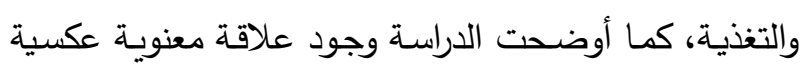

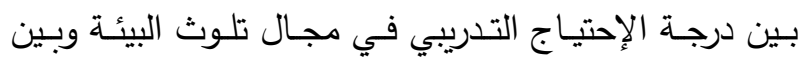

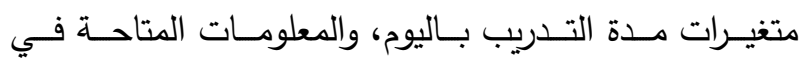
التدريب، والإستفادة من التدريب عند بداية الخدمة، والإستفادة

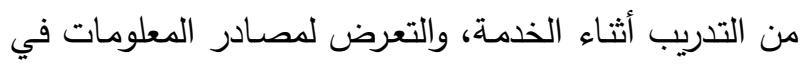

المجتمعـات الناميـة بصـفة خاصـة بسـبب ضــف الـوعى

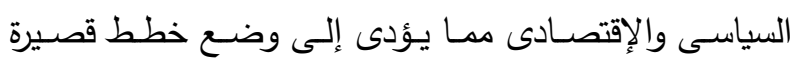
الددى وإتخاذ قرارات متسرعة، لهذا فان غياب التخطيط الجيد

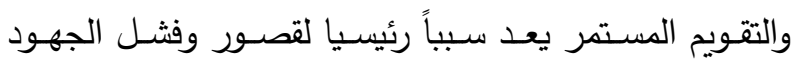
الإرشادية فى المناطق الريفية (Crestvao, 1997). ويعتمد نجاح الإرشاد الزراعى الذى يمثل حجر الزاوية الألية

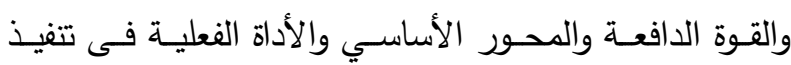
ونجاح البرامج التتمويـة الريفية الإرشادية إلى حد كبير فى الدى

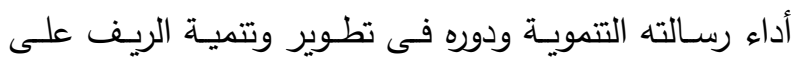
المرشدات الزراعيات من حيث كفائتهن ومهاراتهن وخبراتهن

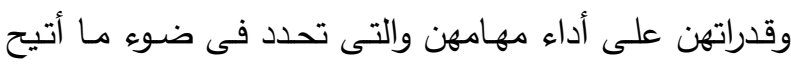
لهن من خبرات تعليمية وتدريبية قبل وأثناء مزاولتهن للعمل

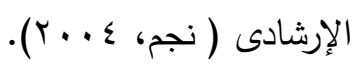

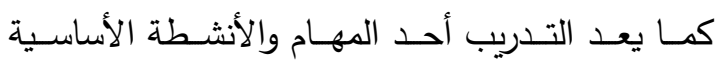
والضرورية والإستراتيجية لإستثمار وتتمية العنصر البشرى والتى يمكن من خلالها تحسين كفاءة المرشدات الزراعيات والإرتقاء بمستوياتهن المعرفية والأدائية وتحديث إمكانياتهن وقدراتهن الفكرية ودعم إتجاهتهن وخبراتهن العملية والعلمية السليمة لجعلهن أكثر إستعداداً لإستيعاب وتقبل وسائلئل التقدم

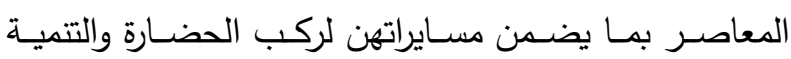

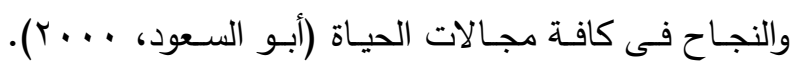
ويعتبر تحديد الإحتياجات التدريبية الخطوة الأولى والأساسية

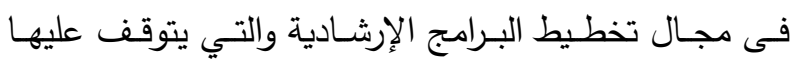
تحديد أهداف التدريب ومجالاته.

وقد أوضــت بعض الدراسـات السـابقة التـي أجريت

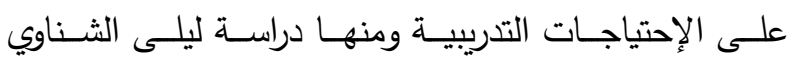
(1990) بعنوان الإحتياجات التدريبية للمرشدات الزراعيات

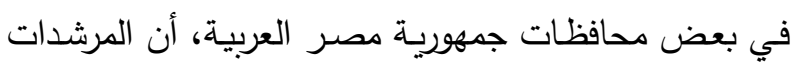
الزراعيات في حاجة إلى التدريب في مجال تخطيط وتقييم

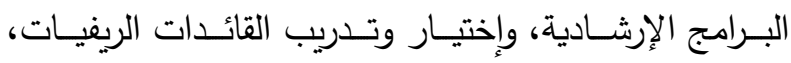
والتتسيق مع المنظمات العاملة في مجال تتمية المرأة الريفية. 


$$
\text { مجلة الإسكندرية للتبادل العلمى - (مجلد \& العدد r) ابريل - يونيو ابr r }
$$

التدريبية للمبحوثات فى مجال تخطيط البرامج الإرشادية

للحفاظ على البيئة الريفية.

ع- التعرف على المعوقات التى تواجه المرشدات الزراعيات

المبحوثات أثناء التدريب.

\section{الفروض البحثية:}

الفرض الأول: توجد علاقة إرتباطية معنوية بين كل من

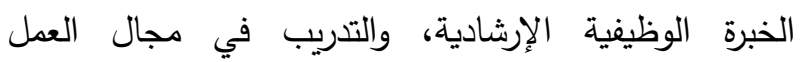
الإرشادي الزراعي، والتدريب فى مجال البيئة، والإتجاه نحو تتمية المرأة الريفية، والإتجاه نحو حماية البيئة، والتجديدية البيئية، وإدراك المشكلات البيئية، والوعى البيئى، والمعرفة ببعض المفاهيم البيئية وبين متغير الإحتياجات التدربيية للمبحوثات فى مجال تخطيط البرامج الإرشادية للحفاظ على

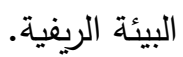

الفرض الثاني: توجد علاقة إرتباطية معنوية بين متغيرات

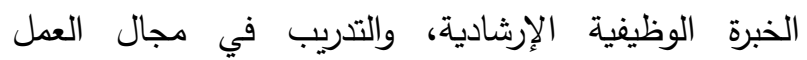
الإرشادي الزراعي، والتدريب فى مجال البيئة، والإتجاه نحو تتمية المرأة الريفية، والإتجاه نحو حماية البيئة، والتجديدية البيئية، وإدراك المشكلات البيئية، والوعى البيئى، والمعرفة ببعض المفاهيم البيئية مجتمعة وبين متغير الإحتياجات التدريبية للمبحوثات فى مجال تخطيط البرامج الإششادية للحفاظ على البيئة الريفية.

الفرض الثالث: يسهم كل من الخبرة الوظيفية الإششادية،

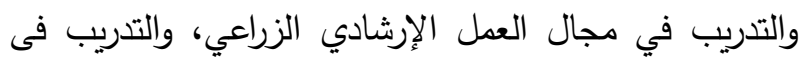
مجال البيئة، والإتجاه نحو تتمية المرأة الريفية، والإتجاه نحو حماية البيئة، والتجديدية البيئية، وإدراك المشكلات البيئية، والوعى البيئى، والمعرفة ببعض المفاهيم البيئية إسهاماً معنوياً فريداً في تفسير التباين في متغير الإحتياجات التدربية للمبحوثات فى مجال تخطيط البرامج الإرشادية للحفاظ على لى

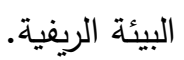

مجـال التغذيـة والبيئــة، ودرجـة التجديديــة، والإتجــاه نحـــ التدريب، ودافعية الإنجاز •

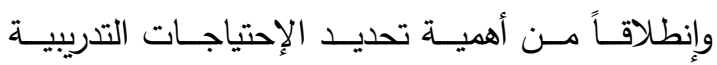
للمرشدات الزراعيات حيث يتوقف عليه بناء البرامج التدريبية القائمـة على إحتياجـاتهن الفعليـة فقـد إنطلقـت هذه الدراســة لتحديد الإحتياجات التدريبية للمرشدات الزراعيات في مجال تخطيط البرامج الإرشـادية للحفاظ على البيئة الريغيـة حتى الإحى يتمكن من أداء وإنجاز أدوارهن الإرشادية فى توعية الريفيات بأهمية الحفاظ على البيئة للحد من تلوثها.

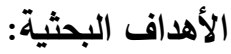

يستهدف هذا البحث بصفة رئيسية قياس الإحتياجات التدريبية للمرشدات الزراعيات المبحوثات فى مجال تخطيط البرامج الإرشادية للحفاظ على البيئة الريفية وذلك من خلال الأهداف الفرعية التالية:

1- التعرف على بعض الخصائص الثخصية للمرشدات

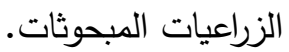

r- التعرف على العلاقات الإرتباطية الثنائية بين كل من الخبرة الوظيفية الإرشادية، والتدريب في مجال العمل الإرشادي الزراعي، والتدريب فى مجال البيئة، والإتجاه نحو تتمية المرأة الريفية، والإتجاه نحو حماية البيئة، والتجديدية البيئية، وإدراك المشكلات البيئية، والوعى البيئى، والمعرفة ببعض المفاهيم البيئية وبين متغير الإحتياجات التدريبية للمبحوثات فى مجال تخطيط البرامج الإرشادية للحفاظ على البيئة الريفية. r- تحديد نسبة إسهام كل من الخبرة الوظيفية الإششادية،

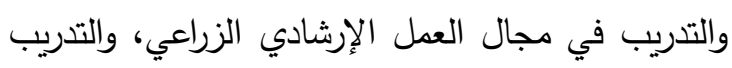
فى مجال البيئة، والإتجاه نحو تتمية المرأة الريفية، والإتجاه نحو حماية البيئة، والتجديدية البيئية، وإدراك المشكلات البيئية، والوعى البيئى، والمعرفة ببعض المفاهيم البيئية في تفسير التباين في متغير الإحتياجات 
هما مؤهل متوسط ، وبكالوريوس. وبعد جمع البيانات تم

إعطاء تلك الإجابتين أوزان ا ب ، ب ؛ على الترتيب.

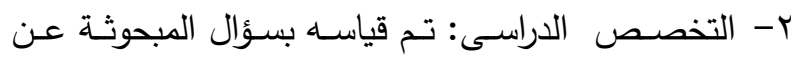

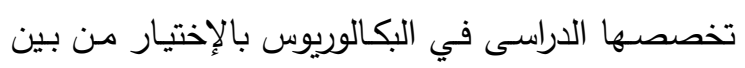

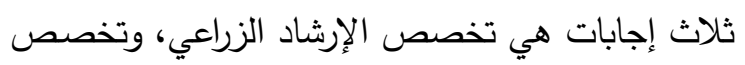

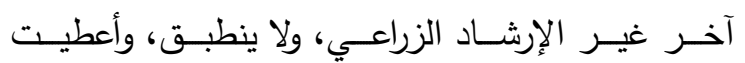
الإجابات أرقام تمييزية ك، اله صفر ؛ على الترتيب.

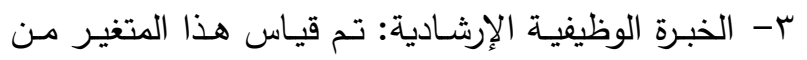
خلال الرقم الخام لعدد سنوات العمل الحكومى للمبحوثة فى مجال الإرشاد الزراعى حتى تاريخ جمع البيانات.

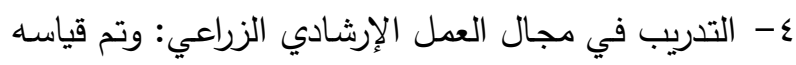

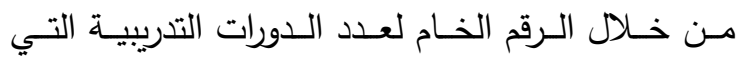
حضرتها المجحوثة في مجال العمل الإرشادي الزراعي وذلك في آخر ثلاث سنوات.

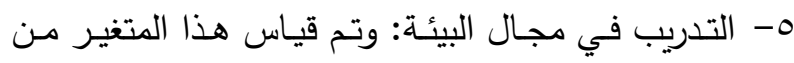
خلال الرقم الخام لعدد الدورات التدريبية التتخصة في في

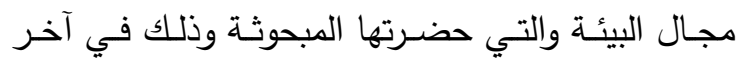

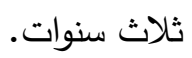
1- الإستفادة من الدورات التدريبية في مجال البيئة: وتم قياس هذا المتغير بسؤال المبحوثة عن مدى إستفادتها

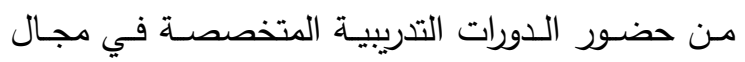

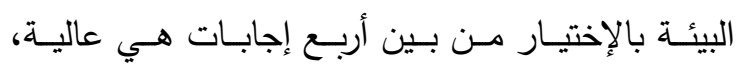
متوسطة، ضعيفة، غير مفيدة، وأعطيت الإجابات أرقام

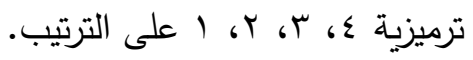

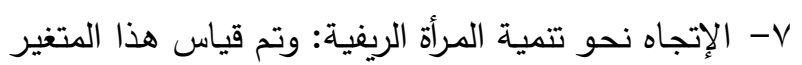
بمقياس مكون من إثنى عشر بنداً، وطلب من المبحوثة الإنة

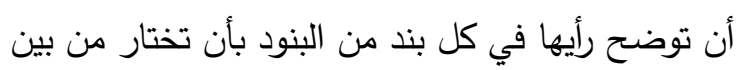

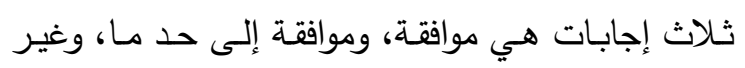

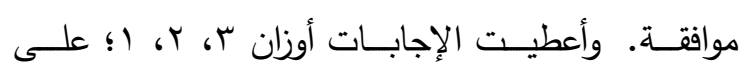

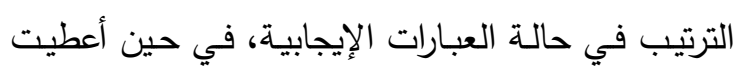

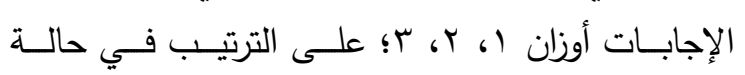

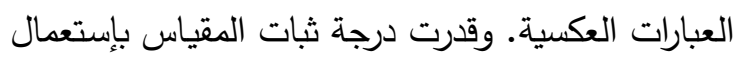

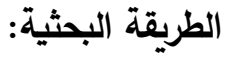
أجريت الدراسة بمحافظة الغربية، حيث يوجد التتظيم

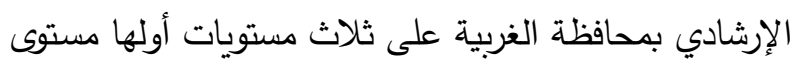

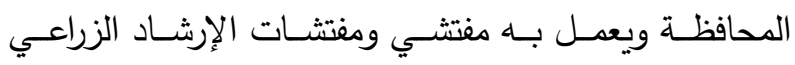

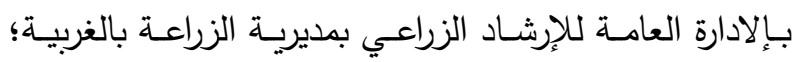

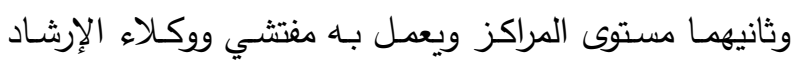

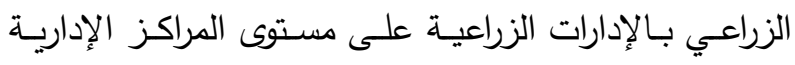

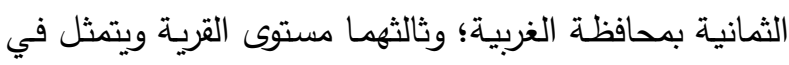
جميع المرشدين والمرشدات الزراعيات وأخصـائيات التتميـة

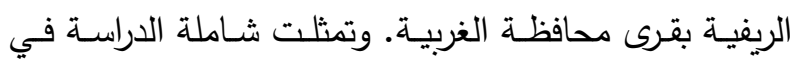

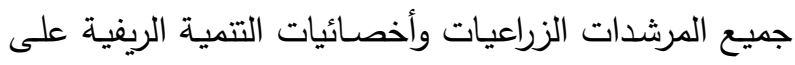

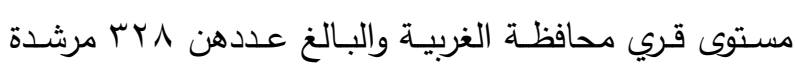

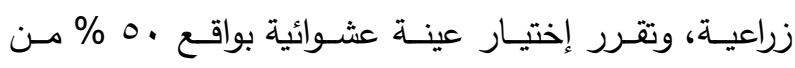

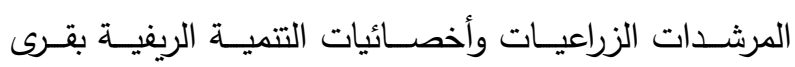
محافظة الغربية، وأسفر الإختيار عن عينة عشوائية مكونة الزئة

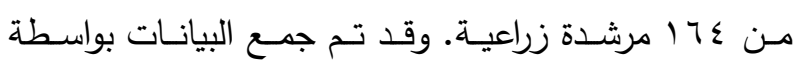

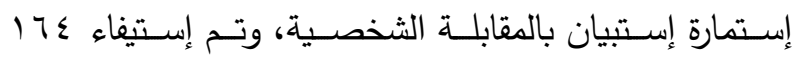
إستمارة تمثل . . 1 \% من العينة المستهدفة. وتم إستخدام

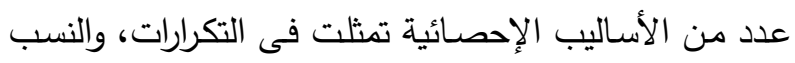

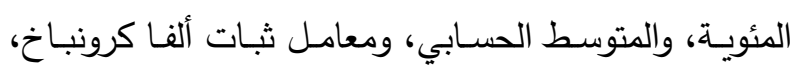
ومعامل الإرتباط البسيط لبيرسون، وأسلوب التحليل الإرتباطي

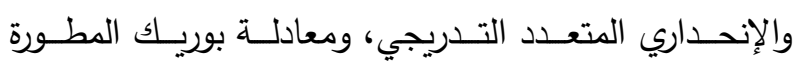
لحساب الإحتياجات التدريبية للمبحوثات. في تحليل بيانات

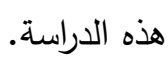
قياس المتغيرات البحثية: - ان

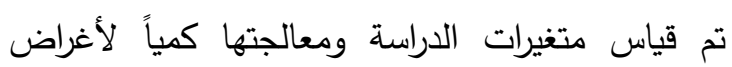

$$
\begin{aligned}
& \text { التحليل الإحصائي على النحو التالي: } \\
& \text { أ - قياس المتغيرات المستقلة : }
\end{aligned}
$$

1- المؤهل الدراسى: وتم قياسه بسؤال المبحوثة عن آخر مؤهل دراسى حصلت عليه بالإختيار من بين إجابتين 


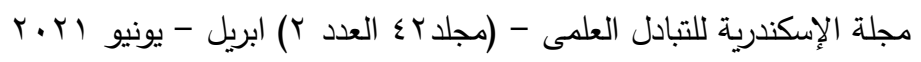

عليهـا المبحوثـة في البنـود المختلفـة لتعبر عن الدرجـة الكلية لمقياس التجديدية البيئية. • - - إدراك المشكلات البيئيـة: وتم قيـاس هـذا المتغيـر بعرض قائمة من أحد عشر مشكلة بيئية على المبحوثة، وطلب مـن المبحوثة أن توضـح رأيها في أضـرار هذه المشكلات البيئية بأن تختار من بين ثلاث إجابات هي لي لهي أضــرار كبيـرة، وأضــرار متوســة، ولا تسـبب أضــرار .

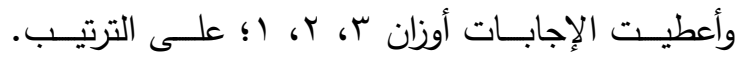
وقدرت درجة ثبات المقياس بإستعمال معامل ثبات ألفا كرونباخ وكان مقداره ا ^. · وهو معامل مرتفع نسبياً.

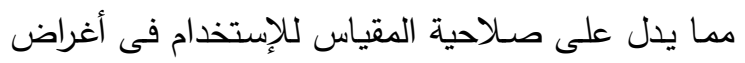
البحث العلمى، وجمعت الدرجات التي حصـلت عليها المبحوثة في المشكلات المختلفة لتعبر عن الدرجة الكلية لمقياس إدراك المشكلات البيئية. 11- الوعي البيئي: وتم قياس هذا المتغير بمقياس مكون

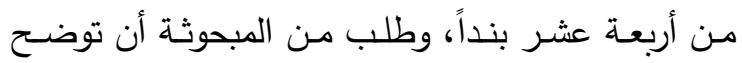
رأيها في كل بند من البنود بأن تختار من بين خمس إجابات هي غير راضية تماماً، وغير راضية، ومحايدة،

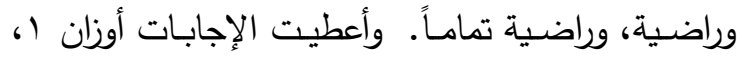

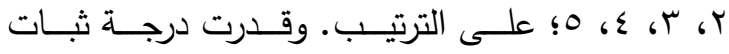
المقياس بإستعمال معامل ثبات ألفا كرونباخ وكان مقداره VA. . . وهو معامل مرتفع نسبياً. مما يدل على صـلاحية المقياس للإستخدام فى أغراض البحث العلمى، وجمعت الدرجات التي حصلت عليها المبحوثة في البنود المختلفة لتعبر عن الدرجة الكلية لمقياس الوعي البيئي.

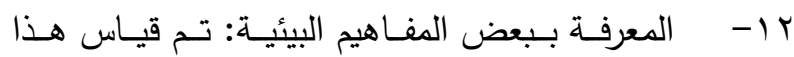
المتغير من خلال مقياس مكون من إحدى وعشرون بنداً تدور حول بعض المفاهيم البيئية مثل التمية المستدامة،

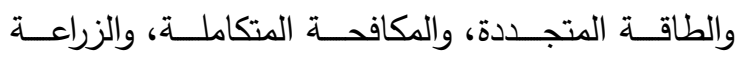

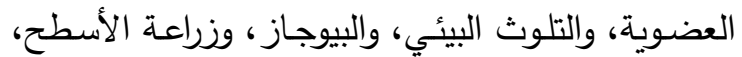

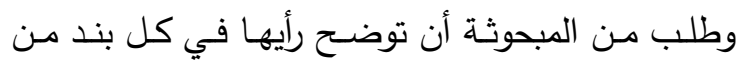

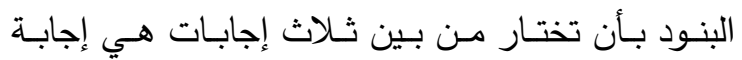

معامـل ثبـات ألفـا كرونبـاخ وكـان مقـداره بV. . وهـو معامل مرتفع نسبياً. ممـا يـدل على صـلاحية المقيـاس للإستخدام فى أغراض البحث العلمى، وجمعت الدرجات مركى التي حصلت عليها المبحوثة في البنود المختلفة لتعبر عـن الدرجـة الكليـة لمقيـاس الإتجـاه نحـو تتميـة المـرأة

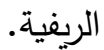
ᄉ- الإتجـاه نحـو حمايـة البيئسة: وتـم قيـاس هــا المتغيـر بمقيـاس مكـون مـن خمسـة عثـر بنـداً، وطلـب مـن

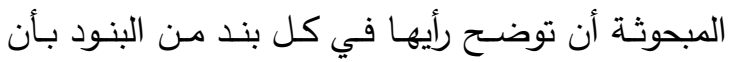
تختار من بين ثلاث إجابات هي موافقة، وموافقة إلى

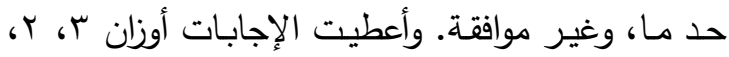
1؛ على الترتيب في حالة العبارات الإيجابية، في حين

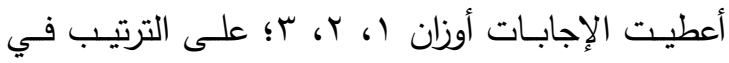

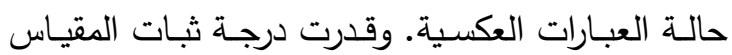
بإستعمال معامل ثبات ألفا كرونباخ وكان مقداره 9 . . وهـو معامـل مرتفـع نسـبياً. مدـا يـدل على صــلاحية المقياس للإستخدام فى أغراض البحث العلمى، وجمعت الـدرجات التي حصـلت عليهـا المبحوثـة فـي البنـود المختلفة لتعبر عن الدرجة الكلية لمقياس الإتجاه نحو

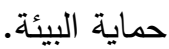
9- التجديدية البيئية: وتم قياس هذا المتغير بمقياس مكون من أربعـة عشر بنداً، وطلب من المبحوثة أن توضـح رأيها في كل بند من البنود بأن تختار من بين ثلاث إجابات هي موافقة، وموافقة إلى حد ما، وغير موافقة.

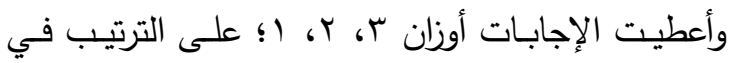
حالـة العبارات الإيجابيـة، في حين أعطيت الإجابـات

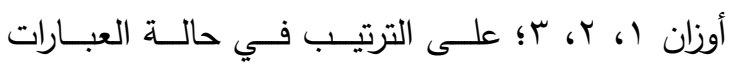
العكسية. وقدرت درجة ثبات المقياس بإستعمال معامل ثبات ألفا كرونباخ وكان مقداره YA. . وهو معامل مرتفع نسبياً. مما يدل على صـلاحية المقياس للإستخدام فى مرونى أغراض البحث العلمى، وجمعت الدرجات التي حصلت 
الثـق الثانى يركز على درجـة أهمية الموضـوع ودرجـة

الإستخدام دون إشتراط معرفة الفرد للموضوع.

وبناء على ما سبق فقد تقرر إستخدام معادلة بوريك

المطورة في قياس الإحتياجات التدريبية للمبحوثات فى مجال

تخطيط البرامج الإشادية للحفاظ على البيئة الريفية، وقد تم

قياس هذا المتغير من خلال مقياس مكون من إحدى الإنساه

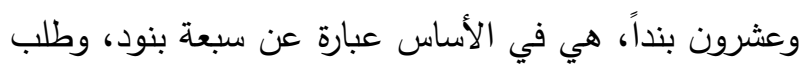
من المبحوثة أن توضح درجة معرفتها بكل بند من البنود وذلك بالإختيار من بين ثلاث إستجابات هي معرفة كبيرة، ومعرفة متوسطة، ومعرفة صغيرة؛ وأعطيت الإجابات أرقام تمييزية r، Y Y، I على الترتيب. ثم طلب من المبحوثة أت توضح أهمية كل بند من البنود وذلك بالإختيار من بين ثلاث إستجابات هي هامة، هامة إلى حد ما، وغير هامة؛ وأعطيت

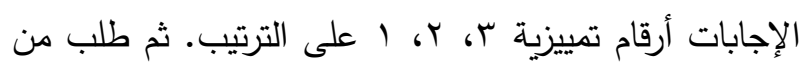
المبحوثة أن توضح مدى قيامها أو تنفيذها لكل بند من البنود وذلك بالإختيار من بين ثلاث إستجابات هي أنفذها دائماً، وأنفذها أحياناً، ولا أقوم بتتفيذها؛ وأعطيت الإجابات أرقات بات هات

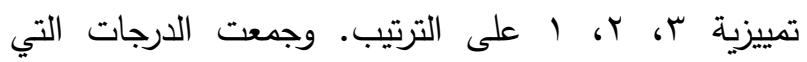
حصلت عليها المبحوثة في كل مكون من المكونات الثلاثة المعرفة والأهمية والإستخدام وذلك تمهيداً لتطبيق معادلة بوريك المطورة لحساب الإحتياجات التدريبية للمبحوثات فى

مجال تخطيط البرامج الإرشادية للحفاظ على البيئة الريفية. الأساليب الإحصائية المستخدمة فى الاراسة:

بعد جمع البيانات تم ترميزها، وتقريغها، وجدولتها وفقا

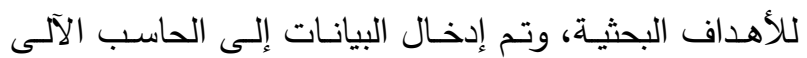

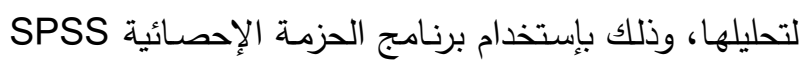
الإصدار الثاني والعشرون، وقد تم إستخدام أساليب التكرارات، والنسب المئوية، والمتوسط الحسابى، ومعامل الإرتباط البسيط

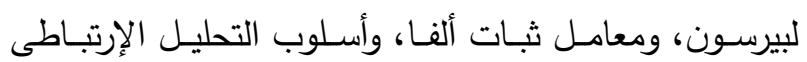
Stepwise Multiple والإنحدارى المتعدد التدريجى ومئي Correlation and Regression
صحيحة، ولا أعرف، وإجابة خاطئة. وأعطيت الإجابات

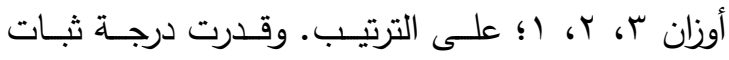
المقيـاس بإسـتعمال معامـل ثبـات ألفـا كرونبـاخ وكـان

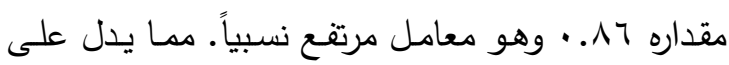
صلاحية المقياس للإستخدام فى أغراض البحث العلمى، وجمعت الدرجات التي حصلت عليها المبحوثة في البنود المختلفة لتعبر عن الدرجة الكلية لمقياس المعرفة ببعض المفاهيم البيئية. قياس المتغير التابع: - 20 - n ويتمثل المتغير التابع للبحث في الإحتياجات التدربيية للمبحوثات فى مجال تخطيط البرامج الإرشادية للحفاظ على البيئة الريفية، وقد تم الإستعانة بمعادلة حساب الإحتياجات التدريبية التي قدمها بوريك 191 . Borich والتي أطلق عليها في الأدبيات معادلة بوريك المطورة أو المعدلة

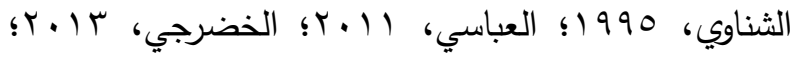
عطية، 9 (Y)، جيث أشارت كثير من الدراسات والأبحاث إلى أهمية إستخدام هذا النموذج في قياس الإحتياجات التدريبية نظراً للمصداقية الكبيرة لهذا النموذج فيما يتصل بتحديد إدراك المستهدفين للإحتياجات التدربيية، وذلك لإعتماد هذا النموذج على ثلاثة أبعاد هي الأهمية والمعرفة

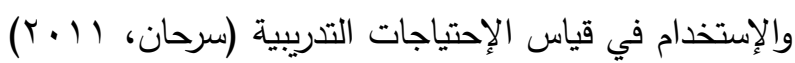
ويمكن قياس الإحتياجات التدريبية وفقاً لمعادلة بوريك

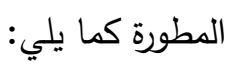
الإحتياج التدريبي = [ (درجة أهمية الموضوع - درجة المعرفة به) × درجة أهمية الموضوع) ] + [ (درجة أهمية الموضـوع - درجـة إستخدام الموضـوع ) × درجـة أهمية

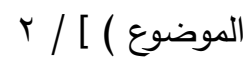

وبتدقيق النظر للمعادلة يتضح أنها تتكون من شقين: الثق الأول يركز على أهمية الموضوع ودرجة المعرفة به دون إشتراط درجة إستخدام الفرد للموضوع. 
توضـــح بيانـات جـدول ( (1) أن مــا يزيــــ عـن ثلثـي المبحوثـات حاصــلات علـى مؤهـل متوسـطـ، وأن الغالبيــة العظمى منهن غير متخصصات في الإرشاد الزراعي، وأن ما يزيد عن ثلث المبحوثات خبرتهن الوظيفية بالإرشاد الزراعي هيري

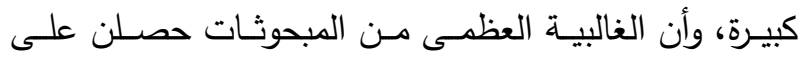
دورات تدريبية في مجال العمل الإرشادي الزراعي، وأن
لوصف البيانـات، وإختبـار العلاقـة بـين المتغيـرات المستقلة مجتمعة وبين المتغير التابع. نتائج الدراسة أسفرت الاراسة عن النتائج التالية: أولاً: الخصائص الثخصية للمبحوثات

جدول ا توزيع المبحوثات وفقاً لبعض خصائصهن الثخصية

\begin{tabular}{|c|c|c|c|c|c|}
\hline النئية & 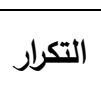 & الإتجاه نحو تنمية المرأة الريفية & النسبة المئوية & 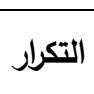 & المؤهل الاراسي \\
\hline .7 & 1 & منخفض ( Y - . ץ ) درجة & $V \cdot V$ & 117 & مؤهل متوسط \\
\hline 00.0 & 91 & متوسط (' ا r ^ r ) درجة & rq. r & $\varepsilon \wedge$ & بكالوريوس زراعة \\
\hline$\varepsilon r .9$ & $V Y$ & مرتفع ( q - - - ) درجة & $1 \ldots$ & $17 \varepsilon$ & الاحمال \\
\hline $1 \cdots$ & $17 \varepsilon$ & 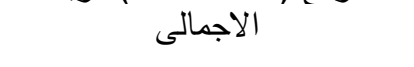 & $1 \ldots$ & 112 & الإجمالي \\
\hline المئوبة & التكرار & الإتجاه نحو حماية البيئة & النسبة المئوية & التكرار & التخص الاراسي \\
\hline r.l & 0 & منخفض ( 10 - §Y ) درجة & 9.1 & 10 & تخصص الإرشاد الزراعى \\
\hline$\varepsilon r .1$ & 79 & 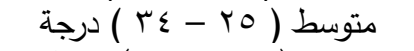 & $9 \cdot .9$ & $1 \leq 9$ & تخصص غير الإرشاد الزراعى \\
\hline $\begin{array}{l}0 \leqslant .1 \\
1 \ldots\end{array}$ & $\begin{array}{l}9 . \\
17 \varepsilon\end{array}$ & مرتفع ( (هب - 0ء ) درجة & $1 \ldots$ & $17 \varepsilon$ & 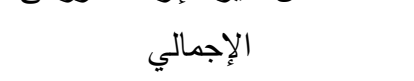 \\
\hline المئوبية & التكرار & التجديدية البيئية & النسبة المئوية & 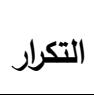 & الخبرة الوظيفية الإرشادية \\
\hline 10.9 & ry & 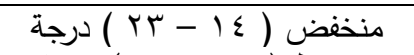 & Tr.q & $0 \leqslant$ & صغيرة (1 - · (1) سنة \\
\hline$\varepsilon \vee .7$ & v^ & متوسط ( §Y - س ) درجة & YY.Y & 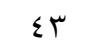 & متوسطة (1) - · ب) سنة \\
\hline r4.0 & 7. & مرتقع ('گ - - rع ) درجة & $\varepsilon . .9$ & TV & كبيرة ('ا' - •r) سنة \\
\hline $1 \ldots$ & $17 \varepsilon$ & 'الاجمالى ' & $1 \ldots$ & $17 \varepsilon$ & الإجمالى \\
\hline النئبة & التكرار & إدراك المشكلات البيئية & النسبة المئوية & 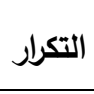 & التراعِى فى مجأل العمل الإرشادي \\
\hline صفز & صفر & منخفض ( I (1 - 1 ) درجة & r.V & 7 & لم تحصل على دورات تدريبية \\
\hline $7 \varepsilon .7$ & 1.7 & متوسط (' 19 - צr ) درجة & $r \varepsilon . \wedge$ & ov & تلقت عدد ( 1 - 0 ) دورة \\
\hline ro.s & $0 \wedge$ & مرتفع ('TV - rr ) درجة & $\varepsilon r . r$ & v) & تلقت عدد ( 7 - . 1 ) دورة \\
\hline $1 \ldots$ & $17 \varepsilon$ & 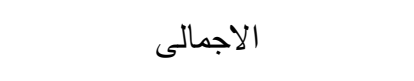 & $\begin{array}{l}11 . r \\
1 \ldots\end{array}$ & $\begin{array}{l}r \\
17 \varepsilon\end{array}$ & تلقت عدد ( (1) - 10 ) دورة \\
\hline المئوبية & التكرار & الوعي البيئي & النسبة المئوية & التكرار & التدريب في مجال البيئة \\
\hline r.V & 7 & منخفض ( צ - Y r ) درجة & 1.0 & $1 \varepsilon$ & لم تحصل على دورات تدرببية \\
\hline 11.1 & אזו & متوسط ('rس - 10 ) درجة & 17.0 & rV & تلقت عدد ( - - r ) دورة \\
\hline $10 . r$ & ro & مرتفع (' or - • ) درجة & TV.1 & 11. & تلقت عدد ( r - ع ) دورة \\
\hline $1 \cdots$ & $17 \varepsilon$ & 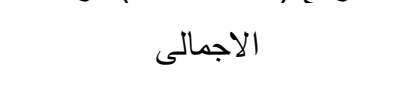 & $\begin{array}{l}v .9 \\
1 \ldots\end{array}$ & $\begin{array}{l}11 \\
17 \leq\end{array}$ & تلقت عدد (مُ0 - الإجمالى 1 ) دورة \\
\hline المئوية & التكرار & المعرفة ببعض المفاهيم البيئية & النسبة المئوية & 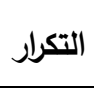 & الإستفادة من التدريب فى مجال \\
\hline 1.0 & $1 \varepsilon$ & منخفض ( ا Y - צr ) درجة & 1.0 & $1 \varepsilon$ & لم تستفيد \\
\hline oV.r & $9 \varepsilon$ & متوسط ('0ب - ^^ ) درجة & $11 .$. & 11 & منخفضة \\
\hline$r \leqslant . r$ & 07 & مرتفع ('qء - ז؟ ) درجة & 71.7 & 1.1 & متوسطة \\
\hline $1 \ldots$ & $17 \varepsilon$ & 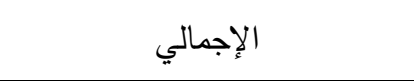 & $\begin{array}{l}11.9 \\
1 \ldots\end{array}$ & $\begin{array}{l}M 1 \\
17 \varepsilon\end{array}$ & 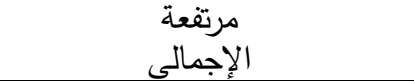 \\
\hline
\end{tabular}


الإرشـادية المناسـبة وعرضـها على الرؤسـاء الترتيـب الثاني بمتوسط حسابي ب.09 درجة، وجاء بند تصنيف المشكلات

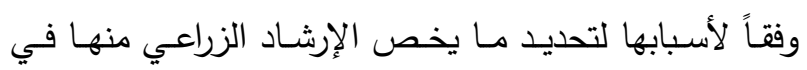

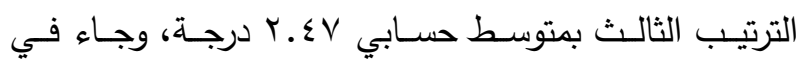
الترتيب الرابع بند رصد أهم أسباب المشكلات البيئية بمتوسط وجس

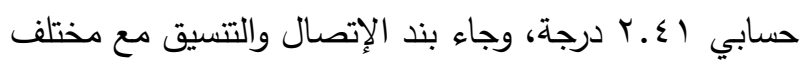

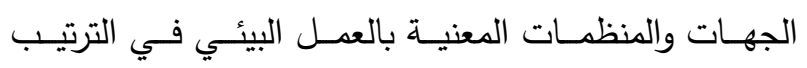

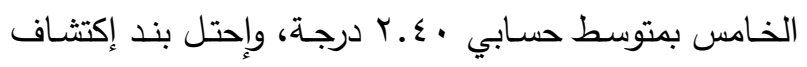

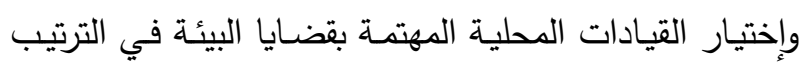

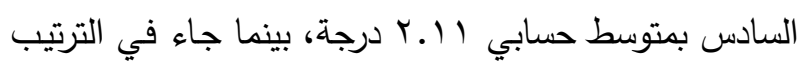
السـابع والأخيـر بنـد الإشتراك في تتفيذ بـرامج حمايسة البيئة

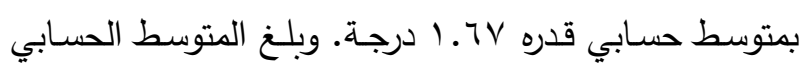
للإحتياج التدريبي الكلي في مجال تخطيط البرامج الإرشادية للحفاظ على البيئة الريفية . . .Y درجة.

\section{ثالثاً: توزيع المبحوثات وفقاً لمستوى الإحتياجات التدربيية}

الكلية

يعرض جدول (r) توزيع المبحوثات وفقاً لمستوى الإحتياجات التدريبية الكلية في مجال تخطيط البرامج الإرشادية للحفاظ على البيئة، وقد تم تقسيمهن وفقاً لمستوى الإحتياجات التدربية إلى ثلاث فئات.
الغالبية العظمى منهن أيضاً حصلن على دورات تدريبية في

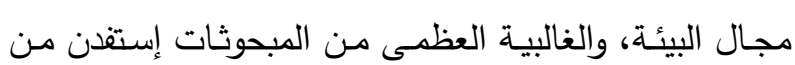
التدريب في مجال البيئة، وأن ما يزيد عن نصف المبحوثات مستوى إتجاهاتهن نحو تتمية المرأة الريفية متوسط، وما يزيد عن نصف المبحوثات مستوى إتجـاههن نحو حمايـة البيئة مرتقع، وما يقرب من نصف المبحوثات يقعن في فئة مستوى التجديديـة البيئيـة المتوسط، ومـا يقرب من ثلثي المبحوثات فئي يقعن في فئة مستوى إدراك المشكلات البيئية المتوسط، وأن

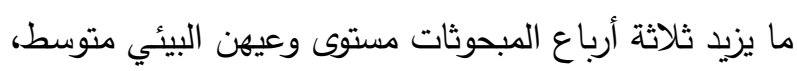

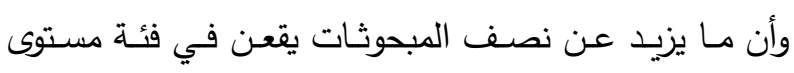
المعرفة ببعض المفاهيم البيئية المتوسط. ثانياً: قياس الإحتياجات التدربية للمبحوثات يعرض جدول رقم (Y) متوسطات درجات الإحتياجات التدريبية المحسوبة لكل بند من بنود مجال تخطيط البرامج

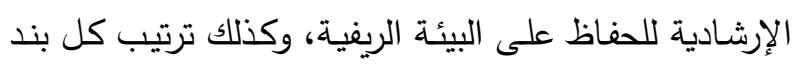
من هذه البنود وفقاً للمتوسط الحسابي للإحتياجات التدربيية للمبحوثات، ومن بيانات الجدول يتضـح أن بند التعرف على

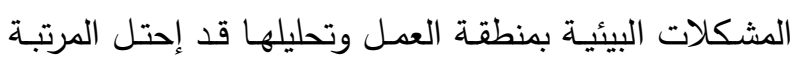

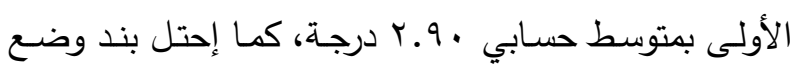

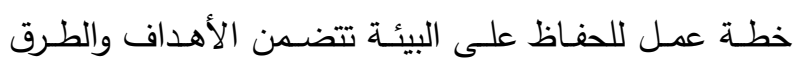

جدول . الإحتياجات التدريبية للمبحوثات فى مجال تخطيط البرامج الإرثادية للحفاظ على البيئة الريفية

\begin{tabular}{|c|c|c|c|}
\hline 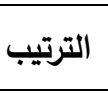 & الحسابى المتوسط & 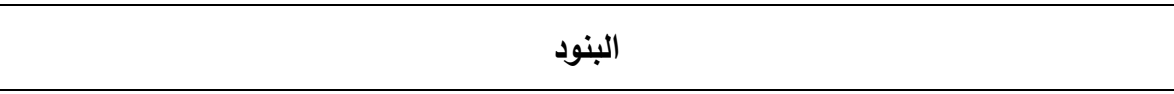 & p \\
\hline 1 & $r, q$. & التعرف على المشكلات البيئية بمنطقة العمل وتحليلها. & 1 \\
\hline$\varepsilon$ & r, § & رصد أهم أسباب المشكلات البيئية. & r \\
\hline r & $Y, \Sigma \vee$ & تصنيف المشكلات وفقا لأسبابها لتحديد ما يخص الإرشاد الزراعى منها. & r \\
\hline 7 & $r, 11$ & إكتثاف وإختيار القيادات المحلية المهتمة بقضايا البيئة. & $\varepsilon$ \\
\hline$\circ$ & $r, \varepsilon$. & الإتصال والتتسيق مع مختلف الجهات والمنظمات المعنية بالعمل البيئى. & ० \\
\hline r & r.,09 & والرؤساء. خطة عمل للحفاظ على البيئة تتضمن الأهداف والطرق الإرشادية المناسبة وعرضها على & 7 \\
\hline v & $1,7 \mathrm{~V}$ & الإشتراك فى تتفيذ برامج حماية البيئة. & $\mathrm{V}$ \\
\hline
\end{tabular}


جدول ب.توزيع المبحوثات وفقا لمستوى الإحتياجات التدريبية

\begin{tabular}{|c|c|c|c|c|}
\hline الانحراف المعياري & المتوسط الحسابي & $\%$ & العدد & فئات مستوى الإحتياجات التدربيية \\
\hline & & $\varepsilon \cdot . \Lambda$ & TV & مستوى منخفض ( صفر - I I I ) درجة \\
\hline 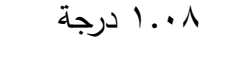 & 1 اء. (1 درجة & $\begin{array}{l}\sum \Lambda . r \\
11 . .\end{array}$ & $\begin{array}{l}\text { va } \\
11\end{array}$ & 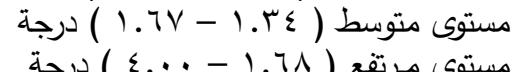 \\
\hline
\end{tabular}

الإرتباط البسيط بين المتغيرات المستقلة المدروسة وبين متغير

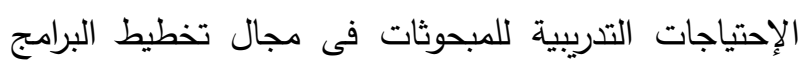
الإرشادية للحفاظ على البيئة الريفية.

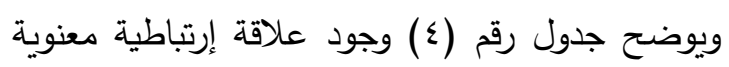
عند مستوى إحتمالي ال... بين متغير الإحتياجات التدريبية

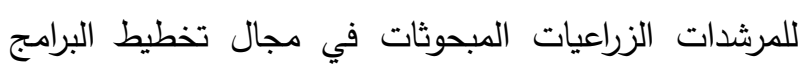

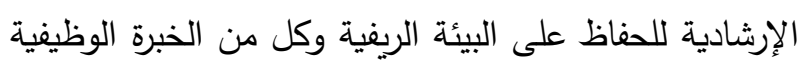

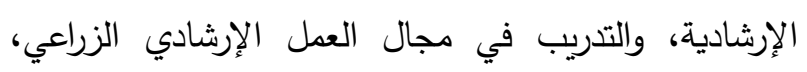

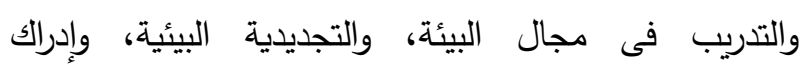
المشكلات البيئية، والوعى البيئى. كما توجد علاقة إرتباطية ولئية

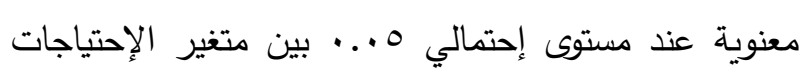

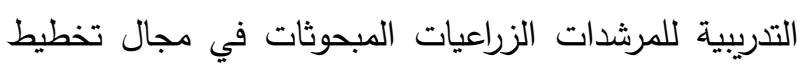
البرامج الإرشادية للحفاظ على البيئة الريفية ومتغير الإتجاه

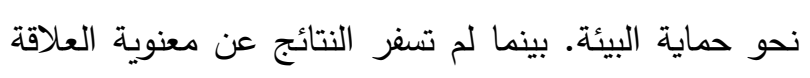
بين متغير الإحتياجات التدريبية للمرشدات الزئلة لتراعيات

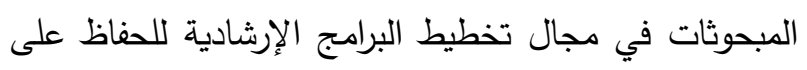
البيئة الريفية ومتغيري الإتجاه نحو تتمية المرأة الأرئادية الريفية،

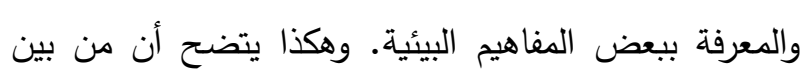

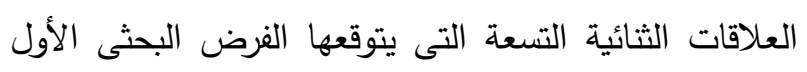

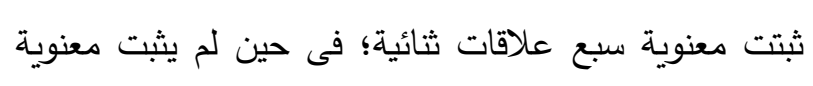

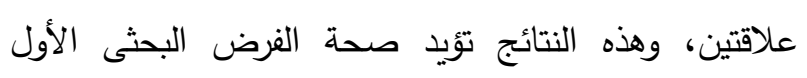
جزئياً. وبناءاً على ذلك يمكن رفض الفرض الإحصائي وقبول الأبل

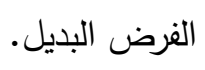

ومن بيانات الجدول يتضح أن ^...؛ \% من المبحوثات

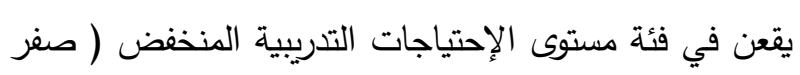

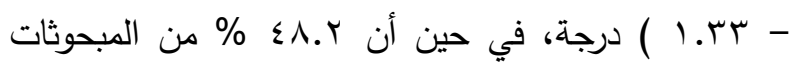

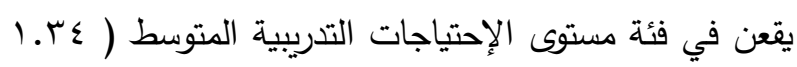

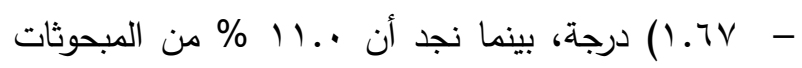

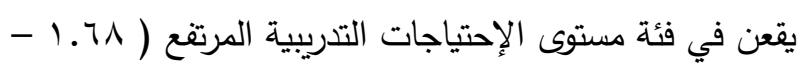

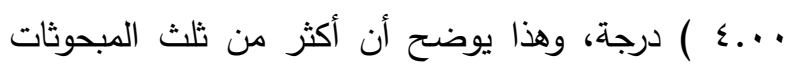

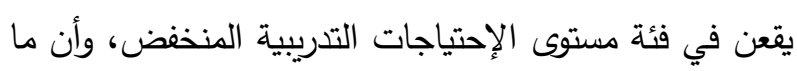
يقرب من نصف المبحوثات ذوي مستوى إحتياج تدريبي

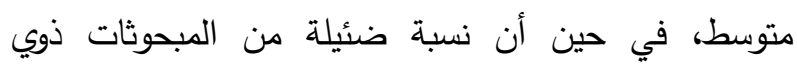
مستوى إحتياج تدريبي مرتفع. رابعاً: العلاقات الإرتباطية بين المتغيرات المستقلة المدروسة منية

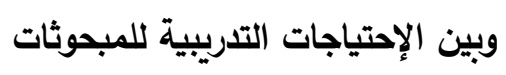

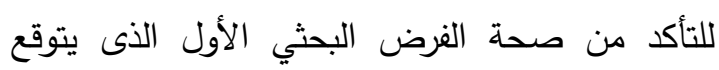
وجود علاقة إرتباطية معنوية بين كل من الخبرة الوظيفية الأنية

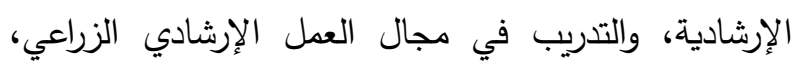

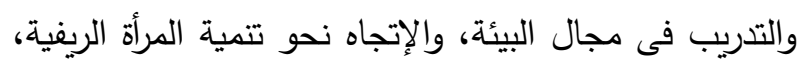

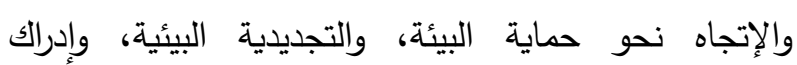

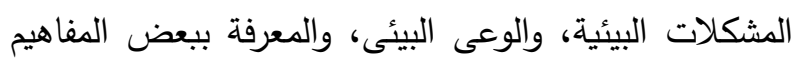

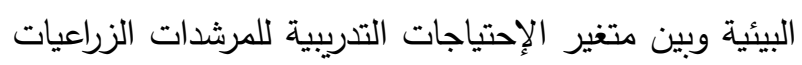

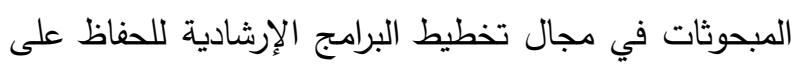
البيئة الريفية؛ تم صياغة الفرض البحثي الأول في صورته

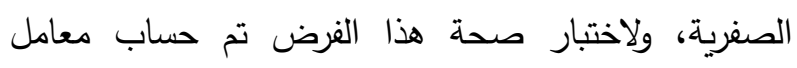




\begin{tabular}{|c|c|c|}
\hline قيم معاملات الارتباط البسيط & المتغيرات المستقلة & s \\
\hline$* *, r V \cdot-$ & الخبرة الوظيفية الإرشادية. & 1 \\
\hline$* *, r \leq r-$ & التدربب في مجال العمل الإرشادى الزراعى. & r \\
\hline **, , YYYー & التدريب فى مجال البيئة. . & r \\
\hline ( & الاتجاه نحو تنمية المرأة الريفية. & $\varepsilon$ \\
\hline$*,, 1 \vee 4$ & الاتجاه نحو حماية البيئة. & 0 \\
\hline$* *, r, q$ & التجديدية البيئية." " & 7 \\
\hline$* *, r \leq V$ & إدرآك" التمشكلات البيئية. & $\checkmark$ \\
\hline$* *, Y Y \leq$ & ألوعى البيئى. & $\wedge$ \\
\hline. .79 & المعرفة ببعض المفاهيم البيئية. & 9 \\
\hline
\end{tabular}

"* عند مستوى معنوية ا ب,.

" عند مستوى معنوية 0 .,.

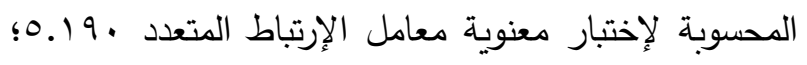

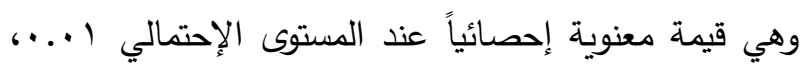
وعليه ينبغي إستتناج وجود علاقة إرتباطية متعددة بين المتغيرات المستقلة مجتمعة وبين متغير الإحتياجات التدربيية للمبحوثات فى مجال تخطيط البرامج الإرشادية للحفاظ على وبين البيئة الريفية، وهذه النتيجة تدعم صحة الفرض البحثي الثاني. ويُشير معامل التحديد إلى أن المتغيرات المسُتقلة

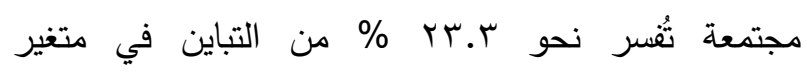
الإحتياجات التدريبية للمبحوثات فى مجال تخطيط البرامج الإرشادية للحفاظ على البيئة الريفية.

ويتوقع الفرض البحثي الثالث أن يسهم كل من الخبرة الوظيفية الإششادية، والتدريب في مجال العمل الإششادي الزراعي، والتدريب فى مجال البيئة، والإتجاه نحو تتمية المرأة الريفية، والإتجاه نحو حماية البيئة، والتجديدية البيئية، وإدراك المشكلات البيئية، والوعى البيئى، والمعرفة ببعض المفاهيم

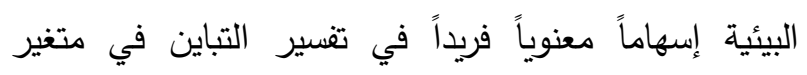
الإحتياجات التدريبية للمبحوثات فى مجال تخطيط البرامج

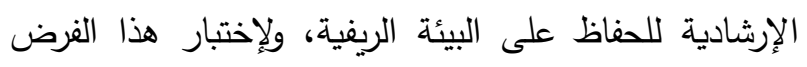
نستعرض قيم معاملات الإنحدار الجزئي المعياري للنموذج الكامل وإختبار معنوياتها الإحصائية وذلك كما في موضح الجدول (0)، حيث يتضح أن ثلاثة متغيرات ذات معاملات إنحدار جزئي معنوي، أي أنها تسهم إسهاماً معنوياً فريداً في
خامســاً: العلاقــات الإنعداربــة المتعـدـدة بـين المتغيـرات المستقلة وبين الإحتياجات التدربيية للمبحوثات في مجال تخطيط البرامج الإرشادية للحفاظ على البيئة الريفية للتأكد مـن صـة الفرض البحثى الثاني الذي يتوقع وجود علاقـة إرتباطيـة معنويـة بين متغيرات الخبرة الوظيفيـة

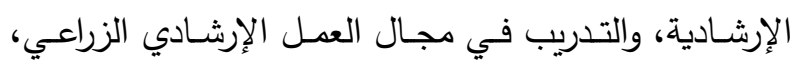
والتدريب فى مجال البيئة، والإتجاه نحو تتمية المرأة الريفية، والإتجــاه نحــو حمايــة البيئـة، والتجديديــة البيئيــة، وإدراك المشكلات البيئية، والوعى البيئى، والمعرفة ببعض المفاهيم

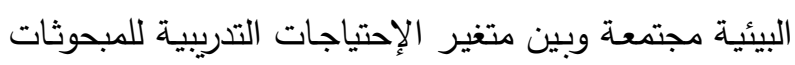
فـى مجـال تخطـيط البـرامج الإرشـادية للحفـاظ على البيئة الريغيـة؛ فقد تم صسياغة الفرض البحثي الثاني فى صسوته الصـفرية، ولاختبـار صـحة هـذا الفـرض تـم حسـاب معادلـة إنحدار متعدد كما في جدول (0) وتثير نتائج معادلة الإنحدار أن متغيرات الخبرة الوظيفية الإرشادية، والتدريب في مجال العمل الإرشادي الزراعي، والتدريب فى مجال البيئة، والإتجاه نحو تتمية المرأة الريفية، والإتجاه نحو حماية البيئة، والتجديدية البيئية، وإدراك المشكلات البيئية، والوعى البيئى، والمعرفة ببعض المفاهيم البيئية مجتمعة ترتبط بمتغير الإحتياجات التدريبية للمبحوثات فى مجال تخطيط البرامج الإرشادية للحفاظ على البيئة

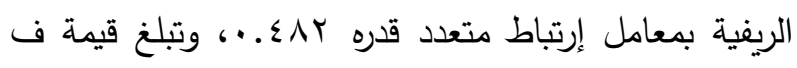




$$
\text { مجلة الإسكندرية للتبادل العلمى - (مجلد \& العدد r) ابريل - يونيو ابr r }
$$

أمكن في هذه الدراسـة حصـر خمسـة عشر معوقاً مـن المعوقات التي قد تمنع عملية التدريب من تحقيق الأهداف

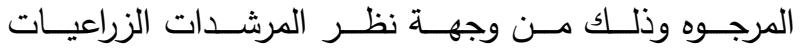
المبحوثـات، حيـث توضــح البيانـات الـواردة بجـدول (7) أن هناك خمسة عشر معوقا من وجهة نظر المرشدات الزراعيات

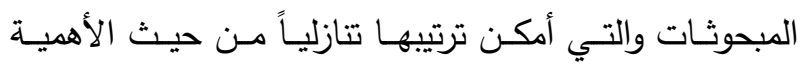
النسبية والتكرار لكل معوق على حده، ويتضـح من بيانـات

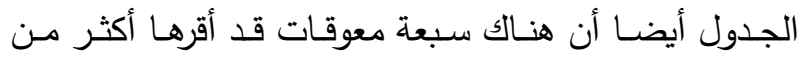
نصف المبحوثات، وجـاء في مقدمـة هذه المعوقات معظم

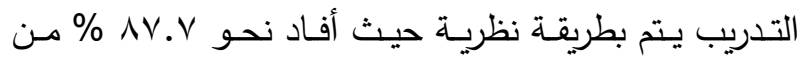
المبحوثات بوجود هذا المعوق. وجاء معوق إستخدام الوسائل التعليمية بشكل غير سليم أثناء التدريب في الترتيب الثاني حيث أقر نحو 1 ا N \% من المبحوثات بوجود هذا المعوق. وجاء معوق بعض المدربين غير قادرين على الثرح في

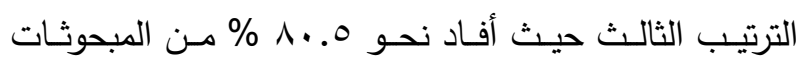

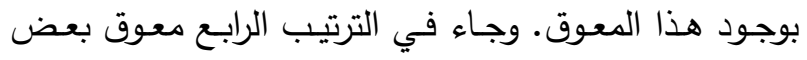
المدربين غير متخصصين في موضسوع التدريب حيث أفاد نحـو 10 10 \% مـن المبحوثات بوجـود هـا المعـوق. وجـاء معسوق عـدم إلمـام بعضض المسدربين بموضـوع التـدريب في

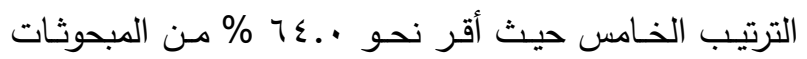
بوجود هذا المعوق. وجاء في الترتيب الساد معوق محتوى التدريب لا يناسب إحتياجات المتدربين حيث أفاد نحو ..

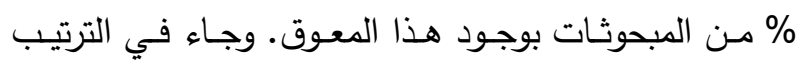

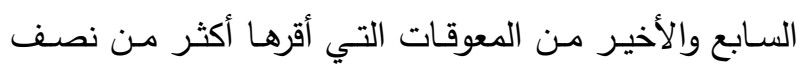
المبحوثات معوق تقديم محتوى التدريب بشكل غير مترابط حيث أفاد نحو . . ب \% \% من المبحوثات بوجود هذا المعوق.

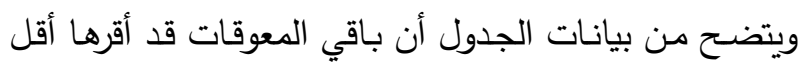
من نصف عدد المبحوثات.
تفسير التباين في متغير الإحتياجات التدريبية للمبحوثات فى مجال تخطيط البرامج الإرشادية للحفاظ على البيئة الريفية، وهذه المتغيرات هي الخبرة الوظيفية الإرشادية، وإدراك المشكلات البيئية، والمعرفة ببعض المفاهيم البيئية. وللوقوف على أكثر المتغيـرات المستقلة تأثيراً على متغير الإحتياجـات التذرببيـة للمبحوثات في مجـال تخطيط البرامج الإرشـادية للحفـاظ على البيئة الريفيـة، تم إستخدام نمـوذج التحليـل الإرتبـاطى والإنحـدارى المتعـدد التـدريجى. وأسفرالتحليل عن معادلة إنحدار خطى متعدد مختزلة تتضمن

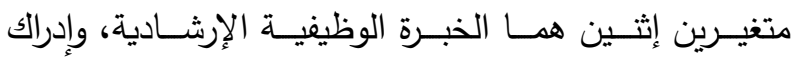
المشكلات البيئية.

ويـرتبط متغيـري الخبـرة الوظيفيـة الإرشـادية، وإدراك المشكلات البيئية بمتغير الإحتياجات التدريبية للمبحوثات فى مجال تخطيط البرامج الإرشـادية للحفاظ على البيئة الريفيـة بمعامل إرتباط متعدد قدرة ؟ ؟ ـ . ، وتبلغ قيمة ف المحسوبة

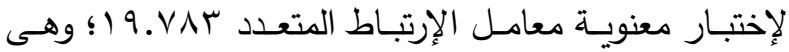

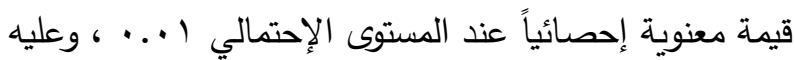
ينبغسى إسـتنتاج وجـود علاقـة إرتباطيـة بـين متغيـري الخبـرة الوظيفيـة الإرشـادية، وإدراك المشكلات البيئيـة وبين متغيـر الإحتياجـات التدريبية للمبحوثات فى مجال تخطيط البرامج الإرشادية للحفاظ على البيئة الريفية. ويشير معامل التحديد

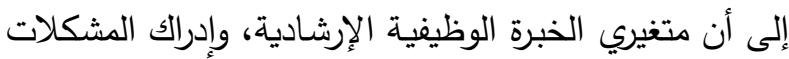
البيئية وحدهما يفسرا نحو 19.9 \% مـن التباين فـى متغير الإحتياجـات التدربيـة للمبحوثات فى مجال تخطيط البرامج الإرشادية للحفاظ على البيئة الريفية. سادساً: المعوقات التي واجهت المبحوثات أثناء التدريب 
جدول ه. العلاقات الانحدارية المتعددة بين المتغيرات المستقلة وبين متغير الإحتياجات التدريبية للمبحوثات

\begin{tabular}{|c|c|c|c|}
\hline \multicolumn{2}{|c|}{ الإحتياجات التدربية للمبحوثات } & \multirow[t]{2}{*}{ المتغيرات المستقلة } & \multirow[t]{2}{*}{ s } \\
\hline النموذج المختزل & النموذج الكامل & & \\
\hline **. & **. . ro. & الخبرة الوظيفية الإرشاددة. & 1 \\
\hline &. .11. & التتربب في مجال العمل الإرشادى الزراعي. & r \\
\hline & ...YI. & التدربب فى مجال البيئة. & r \\
\hline & $.10 \mathrm{~V}$. & الاتجاه نحو تتمية المرأة الربغية. & $\varepsilon$ \\
\hline & $\cdot .1 \cdot \varepsilon$ & الاتجاه نحو حماية البيئة. & 0 \\
\hline & $\cdot .10$ & التجديدية البيئية. & 7 \\
\hline$* * . r \leq 0$ & $* *$ r. ror & إدراك المشكلات البيئية. & V \\
\hline & $\cdots v$ & الوعى البيئح & $\wedge$ \\
\hline & . . & المعرفة ببعض المفاهيم البيئية. & 9 \\
\hline$\rightarrow \leq \leqslant \leq$ &.$\varepsilon \wedge r$ & معامل الارتباط المتعدد R & \\
\hline $.19 \mathrm{~V}$ & מrtrat & معامل التحديد R2 & \\
\hline$* * 19 . \vee \wedge \mu$ & $* 0.19$ & قيمة (ف) F) & \\
\hline
\end{tabular}

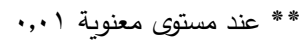

" عند مستوى معنوية 0 .,

جدول 7 معوقات التدربب التى واجهت المبحوثات أثناء التدربب

\begin{tabular}{|c|c|c|c|c|c|}
\hline \multicolumn{2}{|c|}{$y$} & \multicolumn{2}{|c|}{ نعم } & \multirow[b]{2}{*}{ معوقات التدربب } & \multirow[b]{2}{*}{ م } \\
\hline$\%$ & تكرار & $\%$ & تكرار & & \\
\hline$T V, 1$ & 11. & rY,q & $0 \leqslant$ & بعد مكان التدربب وصعوبة الوصول إليه. & 1 \\
\hline$T V, 1$ & 11. & $r$ r,q & $0 \leqslant$ & ضيق مكان التّربب. & r \\
\hline$\vee \wedge$. . & IYA & Tr.. & ז & الضوضاء فى محيط مكان التدربب. & $\mu$ \\
\hline $0 \leqslant, 9$ & 9 . & $\leq 0,1$ & $\vee \varepsilon$ & مكان التدربب غير مرتح. & $\varepsilon$ \\
\hline 71,7 & $1 \cdot 1$ & 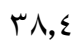 & חוד & ضعف المحتوى الذي يقدم فى التدربب. & 0 \\
\hline rq.. & $7 \varepsilon$ & $71 .$. & $1 \ldots$ & محتوى التدريب لا يناسب إحتياجات المتدربين. & 7 \\
\hline$\varepsilon V_{.} \cdot$ & $\checkmark V$ & or.. & $\wedge \vee$ & تقديم محتوى" التدربب بشكل غير مترابط. & V \\
\hline $01, Y$ & $\Lambda \varepsilon$ & $\varepsilon \wedge, \wedge$ & $\Lambda$. & المحتوى لا يغطى موضوع التدربب. & $\wedge$ \\
\hline$\varepsilon r, q$ & VY & 70,1 & 94 & بعض المدربين غير متخصصين فى موضوع التدريب. & 9 \\
\hline ז.. & 09 & $7 \varepsilon$. & 1.0 & عدم إلمام بعض المدربين بموضوع التدربب. & 1. \\
\hline 19,0 & rt & $\Lambda \cdot, 0$ & rtra & بعض المدربين غير قادرين على الشرح. & 11 \\
\hline Yו, & ro & $\Lambda \vee, \vee$ & 149 & معظم التدربب يتم بطرن & IT \\
\hline 11,9 & ו & $\wedge, 1$ & سبו & إستخدام الوسّائل التعليمية بشكل غير سليم أثناء التدربب. & r \\
\hline$\vee १, 9$ & 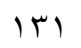 & $r \cdot, l$ & 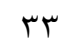 & توقيت التدربب غير مناسب. & $1 \varepsilon$ \\
\hline$T Y, \Lambda$ & $1 \cdot r$ & $r v, r$ & $7)$ & مدة التدربب غير مناسبة. & 10 \\
\hline
\end{tabular}

وعدم إعتبار الإحتياجات التدريبية من الثوابت لأنها في تغير

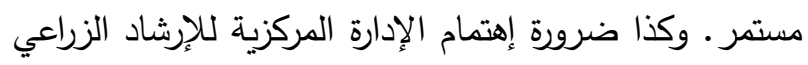
التوصيات

بعقد دورات تدريبية بصفة دورية للمرشدات الزراعيات في في ضوء ما أسفرت عنه نتائج البحث من حاجة مجال تخطيط البرامج الإرشادية للحفاظ على البيئة وذلك المرشدات الزراعيات إلى التدريب في مجال تخطيط البرامج لوجود حاجة إلى التدريب فى هذا المجال. وفي ضوء ما الإرشادية للحفاظ على البيئة الريفية يتضح ضرورة الإهتمام كثفت عنه النتائج من أهمية إستخدام معادلة بوريك المطورة بتقدير الإحتياجات التدربية بصفة دورية للعاملين بالإرشاد لتحديد الإحتياجات التدريبية بدرجة عالية من الدقة أكثر من الن النيه الزراعي بصفة عامة والمرشدات الزراعيات بصفة خاصة وذلك في مجال تخطيط البرامج الإرشادية للحفاظ على البيئة 


$$
\text { مجلة الإسكندرية للتبادل العلمى - (مجلد \& العدد r) ابريل - يونيو اب.r }
$$

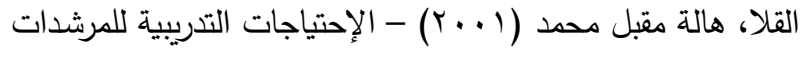
الزراعيات بمحافظة الدقهلية، رسالة ماجستير ، كلية الزراعة،

جامعة المنصورة.

الـنكلاوي، أحمــ (999 (199 ) - أسـاليب حمايـة البيئسة العربيـة مـن

التلوث: مدخل إنسانى متكامل، أكاديمية نايف العربية للعلوم

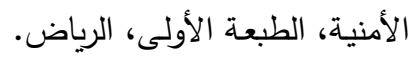

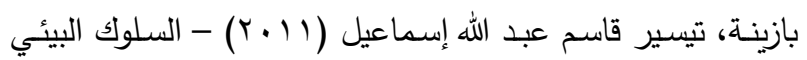

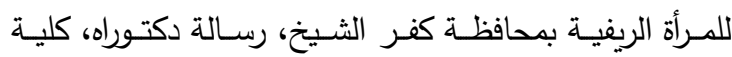

الزراعة، جامعة طنطا.

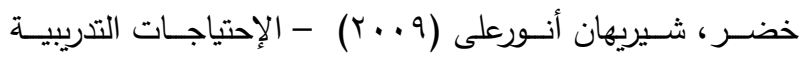

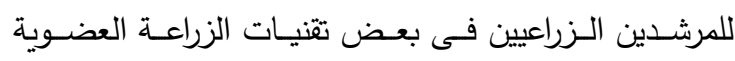

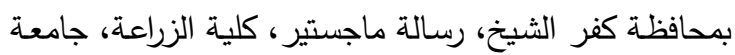
كفر الثيخ. سرحان، أحمد مصطفى محمد (1) (1) - دراسة تحليلية لأولويات الإحتياجـات التدريبية للمرشدين الزراعيين فى مجـال الإدارة

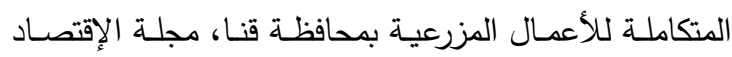

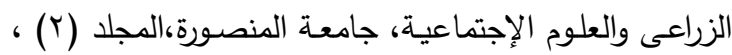

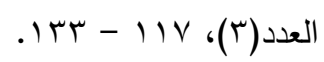

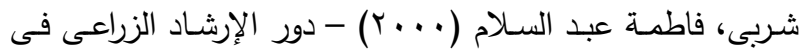

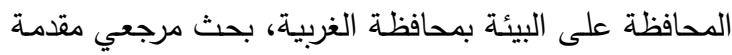

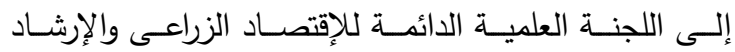
الزراعى والمجتمع الريفى، جامعة الأزهر .

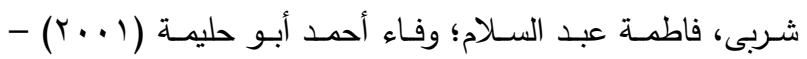
الإتجاهات البيئية للفتيات الريفيات بالمعهد الأزهرى الثانوى

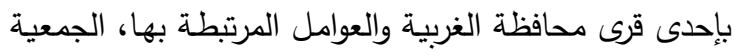

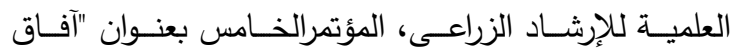

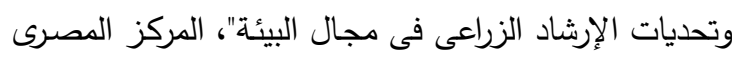

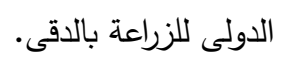

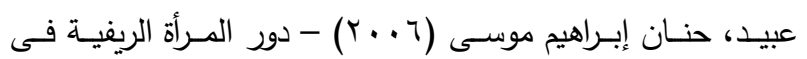

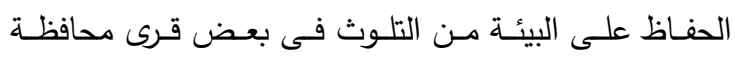
الغربية، رسالة ماجستير ، كلية الزراعة بطنطا، جامعة طنطا.

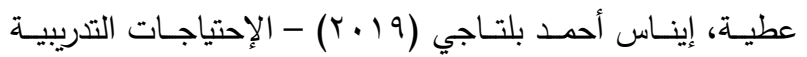
للمرشدات الزراعيات في مجال الحفـاظ على البيئة الريفيـة

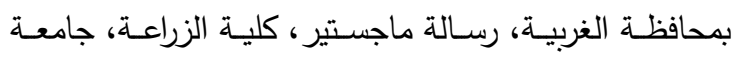
طنطا.
الطرق الأخرى في تقدير الإحتياجات التدربية نظراً لإعتمادها على ثلاثة أبعاد وهي الأهمية والمعرفة والإستخدام مما يزيد من مصداقيتها عند تقدير الإحتياجات التدريبية توصي الدراسة بإستخدامها من قبل الباحثين وذلك لتوفير الوقت، والجهد، والمال عن طريق إعداد برامج تدريبية

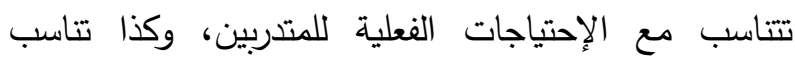
ميزانية التدريب بالجهاز الإرشادي الزراعي.

\section{المراجح}

أبو السعود، خيرى حسن (99V1 ) - التدريب، مشروع دمج الثقافة

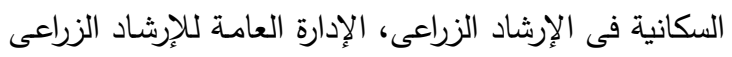

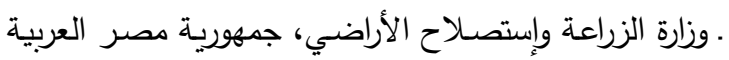

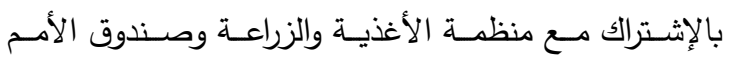
المتحدة للسكان ، القاهرة.

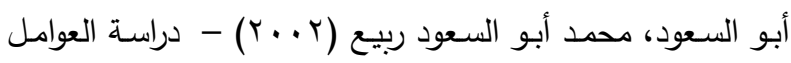
المـؤثرة على سـلوك الـريفيين فـى مجـال حمايـة البيئة مـن

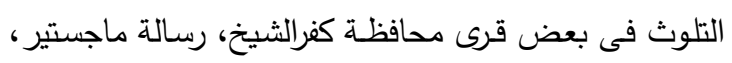
كلية الزراعة بكفر الثيخ، جامعة طنطا.

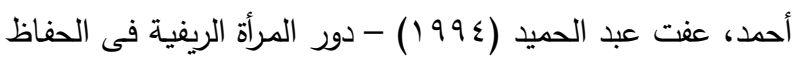
على البيئة، الندوة القومية حول الحفاظ على الموارد البيئية فى الوطن العربى، الدوحة، قطر •

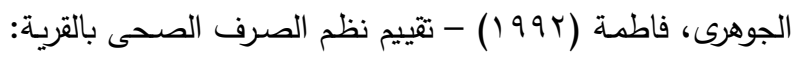

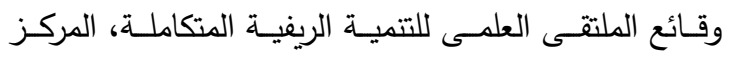
القومى للبحوث وجهاز بناء وتنمية القرية المصرية، القاهرة.

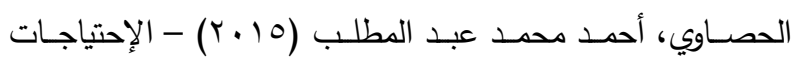
التدريبية للمشرفين الإرشاديين الزراعيين، رسالة دكتوراه، كلية الزراعة، جامعة طنطا. الخضـرجي، منـال محمد على (T (ب) - الإحتياجـات التدريبية

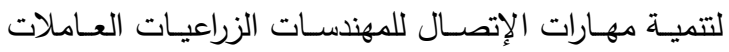
بالإرشاد الزراعي في محافظة الغربية، رسـالة دكتوراه، كلية الزراعة، جامعة طنطا. الثــاوى، ليلى حمـاد (990 (1) - دراســة للسـلوك البيئيسى للمـرأة الريفية ببعض قرى جمهورية مصر العربية، الجمعية العلمية للإرشاد الزراعى، نشرة بحثية رقم (90/1). 
مليحة، أحمد محمد إبراهيم علي (Y (Y) - دور الإرشاد الزراعي

في حمايـة البيئة الريفيـة مسن التلوث بمحافظلة كفر الثـيخ،

رسالة ماجستير ، كلية الزراعة، جامعة كفر الشيخ.

نجم، عمـاد الحسينى على على (ع . . ب) - مصـادر معلومسات

المرشدين الزراعيين فى مصر ، رسالة دكتوراه، كلية الزراعة،

جامعة القاهرة.

Borich, D., (1980). A needs assessment model for conduction follow-up studies, Of Teacher Education, Vol (31), No (3), 39-42.

Crestvao, A.; Koehnon, T.; and Portela, J., (1997). Improving Extension- A Reference Manual, FAO, Rom.

$$
\begin{aligned}
& \text { عمر، أحمد محمد (Y991 (19) - الإرشاد الزراعى المعاصر ، مصر } \\
& \text { للخدمات التعليمية، القاهرة. }
\end{aligned}
$$

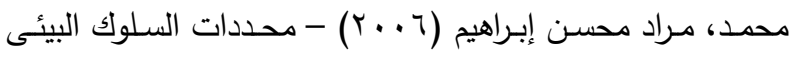

$$
\begin{aligned}
& \text { للزراع بمحافظة كفر الثيخ، رسالة دكتوراه، كلية الزراعة بكفر } \\
& \text { الشيخ، جامعة طنطا. } \\
& \text { محمد، هبـه عبد الفتاح شحته (ع ا • ب) - الإحتياجـات التدريبية } \\
& \text { للمرشدات الزراعيات في مجال التغذية والبيئة، رسالة دكتوراه، } \\
& \text { كلية الزراعة، جامعة القاهرة. }
\end{aligned}
$$

\title{
ABSTRACT \\ Training Needs for Female Agricultural Extension Agents in Planning Extension Programs to Preserve the Rural Environment in Gharbia Governorate
}

\author{
Al-Gohary,A.M., Attia,E.A. and El-Shennawy,L.H.
}

This study was conducted to assess the training needs of female agricultural extension agents in planning extension programs to preserve the rural environment in Gharbia governorate by using Borich modified equation (1980). A random sample of 164 agricultural extension female agents was drawn from the village-level extension female agents in Gharbia governorate. Data were collected from sample persons by personal interview using a structured interview schedule. Collected data were coded and analyzed using the SPSS package.

The main findings of the study could be summarized as follows: -

1- There were statistically significant bivariate relationships at the level of 0.01 of significance between the variable of training needs of female agricultural extension agents in planning extension programs to preserve the rural environment and between variables of extension work experience, training in agricultural extension work, training in the field of environment, environmental renewability, perception of environmental problems, and environmental awareness; ; Also there were statistically significant bivariate relationships at the level of 0.05 of significance between the variable of training needs of female agricultural extension agents in planning extension programs to preserve the rural environment and between the variable of attitudes towards environmental protection; while there were no statistically significant bivariate relationships between the variable of training needs of female agricultural extension agents in planning extension programs to preserve the rural environment and between variables of attitudes towards developing rural women, and knowledge with some environmental concepts.

2- The studied independent variables combined, explained about $23.3 \%$ of the variances of the variable of training needs of female agricultural extension agents in planning extension programs to preserve the rural environment in Gharbia governorate.

Keywords: Training Needs - Extension programs Environment - Gharbia. 